\title{
PENENTUAN HARGA POKOK PENJUALAN PADA UMKN JAMU JAWA ASLI MBAK SUM DI KELURAHAN PEDURUNGAN KIDUL KECAMATAN PEDURUNGAN KOTA SEMARANG
}

\author{
Windasari Rachmawati'), Abdul Karim(1), Vinsensia Retno Widi Wisayang1) \\ 1)Program Studi Akutansi, Fakultas Ekonomi, Universitas Semarang, Semarang, Jawa Tengah, Indonesia \\ Correspondig author: Windasari Rachmawati \\ Email: windasarirachmawati@usm.ac.id
}

Diterima 18 Novemebr 2021, Direvisi 08 Desember 2021, Disetujui 09 Desember 2021

\begin{abstract}
ABSTRAK
Persaingan global memicu adanya ekonomi kreatif yang identik dengan industri kreatif. Untuk peningkatan taraf hidup masyarakat, UMKNjamu jawa asli yang di miliki oleh ibu suminah yang berada di desa pedurungan kidul kecamatan pedurungan kota Semarang, sudah berkecimpung di dalam usaha kecil menengah, tetapi UMKNini belum bisa mengatur keuangan dengan baik. Tim pengabdian masyarakat Universitas Semarang ingin membantu UMKNini di desa pedurungan kidul dengan cara penentuan biaya harga pokok penjualan dan inovasi produk. Dengan melihat peningkatan kesadaran masyarakat akan kesehatan, terutama pada masa pandemik ini, sehingga peningkatan usaha pada UMKNjamu sebagai minuman warisan tradisional nenek moyang semakin dicari masyarakat. Sehingga pendapatan UMKNjamu meningkat, tetapi masih minimnya pengetahuan tentang penentuan harga pokok penjualan membuat UMKNjamu ini masih mencampur aduk dengan kebutuhan pribadi, maka tim pengabdian masyarakat ingin memberikan pelatihan penentuan harga pokok penjualan. Metode yang digunakan dalam kegiatan PKM ini meliputi kegiatan pelatihan dan workshop. Kegiatan pelatihan yang dilakukan meliputi 1) Penentuan harga pokok penjualan dan akuntansi dasar 2) penentuan strategi yang tepat. Kegiatan PKM ini meliputi 1) Pra Survei Lapangan 2) Persiapan Alat dan Bahan Pelatihan 3) Persiapan Tempat Pelatihan dan Workshop 4) Penentuan harga pokok penjualan dan Akuntansi Dasar 5) Penentuan strategi yang tepat dengan pemakaian harga yang sudah ditentukan bagi umk 6) Pembuatan Laporan dan Publikasi. Peran kedua mitra adalah sebagai obyek dan subyek. Sebagai obyek, mitra merupakan sasaran untuk ditangani permasalahannya dalam mengembangkan usaha. Hasilnya UMKNjamu jawa asli semakin bertambah wawasannya tentang penentuan harga pokok penjualan dan diterapkan di pembukuannya.
\end{abstract}

Kata kunci: industri kreatif; penenntuan harga pokok penjualan; jamu jawa

\begin{abstract}
Global competition triggers a creative economy that is identical to the creative industry. To improve people's living standards, MSMEs for indigenous Javanese herbal medicine owned by Mrs. Suminah who are in Pedurungan Kidul village, Pedurungan sub-district, Semarang city, are already involved in small and medium enterprises, but these MSMEs have not been able to manage finances properly. The Semarang University community service team wants to help these SMEs in the village of Pedurungan Kidul by determining the cost of goods sold and product innovation. By looking at the increase in public awareness of health, especially during this pandemic period, so that the increasing number of businesses on herbal medicine as a traditional heritage drink from their ancestors is increasingly sought after by the community. So that the income of herbal medicine MSMEs increases, but the lack of knowledge about determining the cost of goods sold makes these herbal MSMEs still mix up with their personal needs, so the community service team wants to provide training on determining the cost of goods sold. The methods used in this PKM activity include training activities and workshops. The training activities carried out include 1) Determining the cost of goods sold and basic accounting 2) determining the right strategy. This PKM activity includes 1) Pre-Field Survey 2) Preparation of Training Tools and Materials 3) Preparation of Training Places and Workshops 4) Determination of the cost of goods sold and Basic Accounting 5) Determining the right strategy by using prices that have been determined for MSEs 6) Reporting and Publications. The roles of the two partners are as objects and subjects. As objects, partners are targets to deal with problems in developing a business. As a result, indigenous Javanese herbal medicine companies have increased their insight into determining the cost of goods sold and applied it to their books.
\end{abstract}

Keywords: creative industry; determination of cost of goods sold; Javanese herbal medicine 


\section{PENDAHULUAN}

Persaingan global memicu timbulnya ekonomi kreatif yang identik dengan industri kreatif. Pada masa pandemik sekarang ini masyarakat semakin meningkat kesadarannya akan kesehatan. Jamu sebagai warisan leluhur bangsa Indonesia, yang bahan bakunya empon - empon yang mudah ditemui di lingkungan sekitar rumah atau di jual di pasar tradisional atau supermarket. Semakin berkembangnya tekhnologi sekarang ini inovasi jamu bukan hanya di seduh tetapi juga dalam bentuk serbuk. Kemasan produk juga semakin bagus dengan botol - botol plastik dan terdapat merk atau label. Pemasarannya juga tidak hanya di edarkan dengan gendong atau keliling kampung semata. Tetapi sudah merambah hingga pasar modern atau supermarket.

Menurut Soegoto (2009) bahwa kewirausahaan atau entrepreneurship adalah usaha kreatif yang dibangun berdasarkan inovasi untuk menghasilkan sesuatu yang baru, memiliki nilai tambah, memberi manfaat, menciptakan lapangan kerja dan hasilnya berguna bagi orang lain.

UMKNjamu jawa asli yang berada di kelurahan pedurungan kidul kecamatan pedurungan adalah salah satu UMKNjamu yang ada di kota Semarang. UMKNini didirikan oleh ibu suminah dengan memiliki dua karyawan. Dengan lokasi rumah yang dekat dengan pasar pedurungan membuat ibu suminah mudah memperoleh bahan empon empon sebagai bahan baku jamu. Pasar pedurungan juga ditetapkan sebagai salah satu pasar sehat dikota Semarang. Ibu suminah memproduksi jamu dalam bentuk seduh dan serbuk. Dengan permintaan pasar yang semakin meningkat terutama di masa pandemik ini dimana masyarakt meningkat kesadarannya akan kesehatan. secara langsung menambah laba dari UMKNjamu jawa asli. Tetapi kenyataan tidak demikian karena UMKNini masih memiliki masalah di dalam pengelolaan keuangan terutama dalam penentuan harga jual jamu.

Berdasarkan latar belakang di atas, maka tim pengabdian kali ini berupaya untuk membantu UMKNdalam pembuatan pennetuan harga pokok penjualannya. Sehingga UMKNtersebut dapat dengan mudah menghitung laba yang di peroleh selama proses produksi sampai mendapatkan pendapatan dari produk yang dipasarkan. Pada pengabdian masyarakat kali ini diangkat suatu perumusan masalah yaitu bagaimana meningkatkan pengetahuan dan pengelolaan usaha UMKNjamu jawa asli melalui penentuan harga pokok penjualan sehingga dapat meningkatkan pendapatan UMKNjamu jawa asli di kelurahan pedurungan kidul kecamatan pedurungan kota Semarang.

\section{METODE}

Mengenai metode pengabdian yang akan dilaksanakan tentang "Penentuan Harga Pokok Penjualan Pada UMKNJAMU JAWA ASLI Mbak Sum Di Kelurahan Pedurungan Kidul Kecamatan Pedurungan Kota Semarang" berupa presentasi ceramah dan praktek pembuatan produk olahan tahu secara langsung kepada mitra. Adapun penjelasan mengenai metode pelaksanaan kegiatan adalah sebagai berikut dengan cara :

\section{Metode Ceramah}

Dengan metode ceramah ini tim pengabdi melakukan presentasi kepada mitra mengenai pemberdayaan perempuan melalui berwirausaha dengan memberikan penjelasan dan motivasi kepada mitra tentang hal-hal yang perlu dipersiapkan dalam berwirausaha. Selain dengan presentasi juga dilakukan sesi tanya jawab kepada mitra, sehingga diharapkan dengan sesi tanya jawab mitra nantinya akan termotivasi untuk berwirausaha dan pada saat praktek mitra dapat mengikuti kegiatan dengan baik.

\section{Metode Praktik Pelatihan}

Dengan metode praktek secara langsung team pengabdi memberikan kesempatan kepada UMKNmengenai proses penentuan harga pokok penjualan jamu secara langsung. Diharapkan metode praktek ini mampu meningkatkan ketrampilan UMKNjamu jawa asli dalam menggali potensi diri untuk melakukan penghitungan dan pembukuan usahanya.

\section{HASIL DAN PEMBAHASAN}

Urutan kegiatan pengabdian kepada masyarakat yang berjudul "Penentuan Harga Pokok Penjualan Pada UMKNJAMU JAWA ASLI Mbak Sum Di Kelurahan Pedurungan Kidul Kecamatan Pedurungan Kota Semarang" sebagai berikut :

a) Penyuluhan Mengenai Penentuan Harga Pokok Penjualan

Pada kegiatan penyuluhan dilakukan dengan memberikan sosialisasi kepada UMKNjamu jawa asli mengenai penentuan harga pokok penjualan. Dimana UMKN menyadari jika terbatasnya pengetahuan mereka tentang penentuan harga pokok penjualan dan pembukuan, hal ini diperngaruhi oleh belum adanya 
pemberdayaan secara maksimal oleh instansi sekitar.

b) Praktek Mengolah Jamu Instan Jahe Emprit

Pada kegiatan pengabdian ini tim pengabdi memberikan pelatihan mengenai membuat jamu instan jahe emprit. Dimana tim pengabdi menjelaskan mengenai bahan yang diperlukan, tahapantapan proses membuat jamu instan jahe emprit dari awal sampai akhir. Selain ini tim pengabdi menjelaskan dalam membuat jamu emprit ini tidak membutuhkan ketrampilan yang spesifik serta tidak terlalu membutuhkan bahan-bahan yang banyak serta membutuhkan waktu yang sangat singkat. Sehingga diharapkan dengan antusiasnya UMKNmeningkatkan ketrampilan serta kreativitas sebagi proses untuk berwirausaha.

c) Pada tahapan evaluasi terhadap program penyuluhan dan pelatihan ketrampilan dilaksanakan dengan membandingkan keadaan mitra sebelum dan sesudah program kegiatan pengabdian, seperti yang tampak pada Gambar 1.

\section{Sebelum pengabdian kepada masyarakat}

Umkm jamu jawa asli di sapta prasetya kelurahan pedurungan kecamatan pedurungan kidul masih menetapkan harga jual yang relatif tinggi dengan rata rata keuntungan $75 \%$ per produk. Pada masa pendemik saat ini dengan berharap keuntungan yang terlalu tinggi membuat mereka sulit dalam menjual produknya

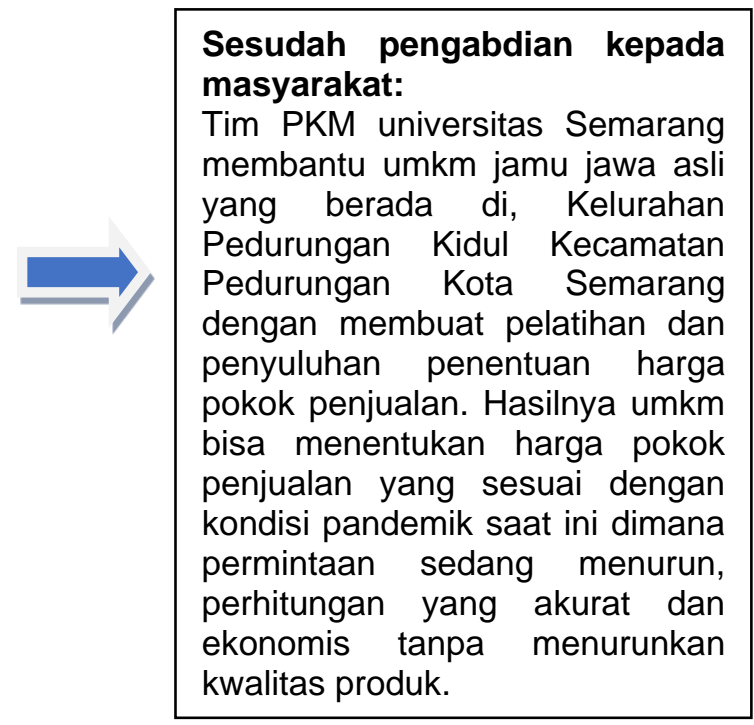

Gambar 1. Sebelum dan Sesudah Pengabdian Kepada Masyarakat

\section{d) Pelaporan}

Tahap pelaporan merupakan tahapan terahir dari kegiatan pengabdian, dimana tim pengabdi melakukan pelaporan akan kegiatan pengabdian yang telah dilakukan pada UMKNjamu jawa asli di kelurahan pedurungan kidul, kecamatan pedurungan.

Pengabdian kepada masyarakat yang telah kami lakukan mengenai Penentuan Harga Pokok Penjualan Pada UMKNJAMU JAWA ASLI Mbak Sum Di Kelurahan Pedurungan Kidul Kecamatan Pedurungan Kota Semarang adalah sebagai berikut :

a) Antusiame dalam kegiatan pengabdian kepada masyarakat ditunjukan oleh UMKNjamu jawa asli dalam kegiatan penyuluhan tentang penentuan harga pokok penjualan, dimana diskusi kita mengenai penentuan harga pokok penjualan untuk pembukuan yang lebih tertib dan teruku, mulai proses menghitung bahan baku dan biaya produksi sampai ke penentuan harga pokok penjualan.

b) Peran aktif UMKN dalam penentuan harga pokok penjualan kepada mitra, pertama team pengabdi memberikan penjelasan mengenai langkah-langkah dalam penentuan harga pokok penjualan. Sehingga diharapkan UMKNakan termotivasi menggali potensi diri dan ketrampilan dalam penentuan harga pokok penjualan. Langkah kedua dengan memberikan pelatihan dengan praktek secara langsung untuk meningkatkan kreativitas kepada UMKNdalam menyusun laporan keuangan. Sehingga diharapkan UMKNgemar mencatat transaksi yang sudah dilakukan dan memiliki gambaran berapa laba yang nantinya akan diperoleh.

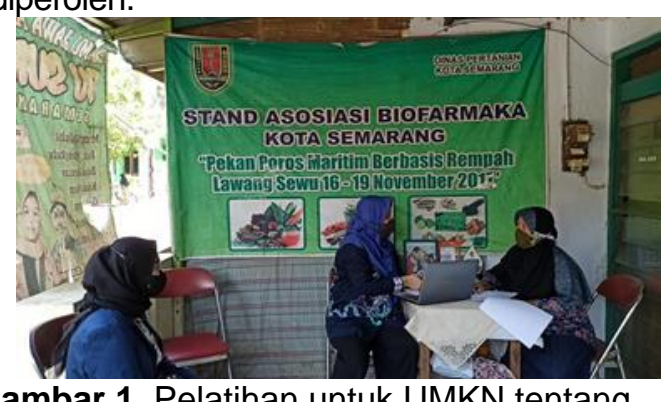

Gambar 1. Pelatihan untuk UMKN tentang penentuan harga pokok penjualan. 


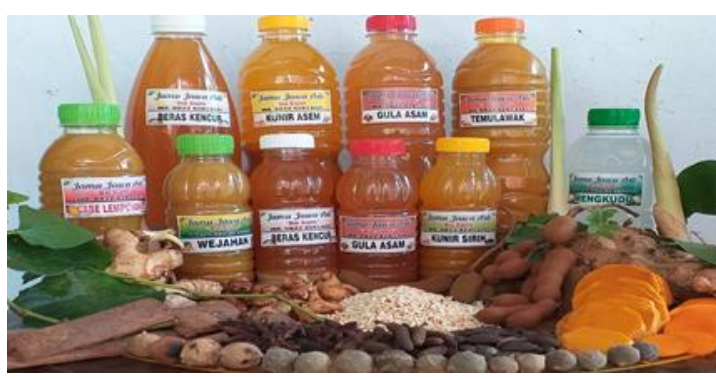

Gambar 2. Produk Jamu UMKNjamu jawa asli

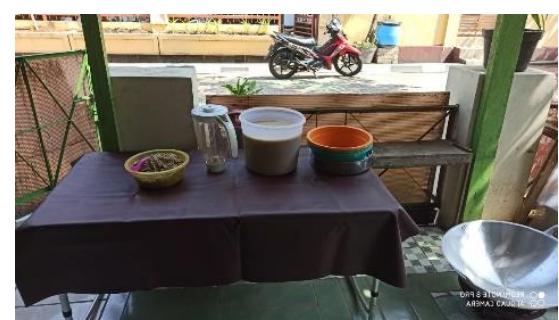

Gambar 3. Proses Produksi Jamu Instan Jahe Merah

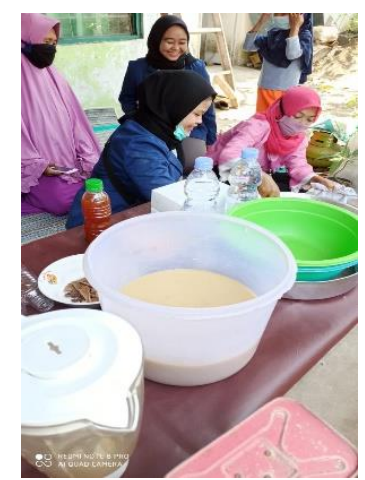

Gambar 4. Proses Produksi Jamu instan

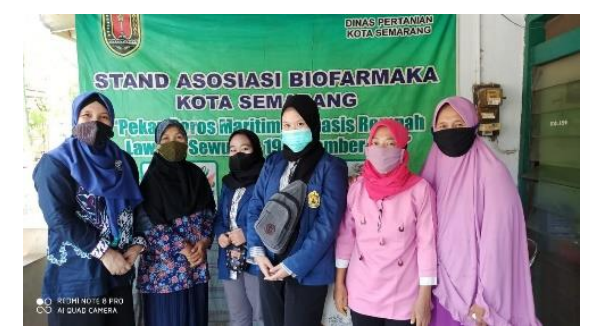

Gambar 5. Foto Bersama UMKNjamu jawa asli

\section{SIMPULAN DAN SARAN}

Dari hasil pelaksanaan pengabdian kepada masyarakat melalui penyuluhan, pelatihan dan praktek penentuan harga pokok penjualan UMKNjamu jawa asli di kelurahan pedurungan kidul kecamatan pedurungan dengan membuat pembukuan dapat disimpulkan sebagai berikut : 1). UMKNjamu jawa asli kelurahan pedurungan kidul kecamatan pedurungan kota semarang termotivasi untuk membuat pembukuan laporan keuangan yang lebih baik; 2). UMKNjamu jawa asli mampu mengolah bahan mentah berupa jahe emprit untuk dijadikan produk siap konsumsi berupa jamu serbuk. sehingga akan meningkatkan nilai jual jahe merah atau emprit tersebut dan berpeluang untuk dijadikan proses berwirausaha.

UMKNjamu jawa asli jangan takut untuk membuat laporan keuangan, karena dengan adanya laporan keuangan yang tertib dan teratur membuat mereka bisa lebih meningkatkan income atau pendapatan.

\section{UCAPAN TERIMAKASIH}

Lembaga Penelitian dan Pengabdian Kepada Masyarakat Universitas Semarang

\section{DAFTAR RUJUKAN}

Aisyah, irwan (2018), "Pengembangan Industri Kreatif Di Kota Batu (Studi Tentang Industri Kreatif Sektor Kerajinan di Kota Batu)",Jurnal Administrasi Publik Vol.2.No.2

Jong \& Wennekers. (2008). "Conceptualizing Entre- preneurial Employee Behavior", SMEs and Entrepreneurship Programme Finance by the Netherlands Ministry of Economic Affairs.

Nenden (2020)," Produktivitas Jamu Pada Masyarakat Argomulyo Di Masa Pandemi", Jurnal Ekonomi Dan pendidikan

Purwantisari (2021), "Produk Serbuk Jamu Instan Dengan Alat Kristalisasi Di Kecamatan Ungaran Timur Kabupaten Semarang",jurnal EDIMAS , 2019, Monografi Kelurahan Meteseh, Kecamatan Tembalang, Kota Semarang

https://www.jurnal.id/id/blog/2018-tips-suksesmenerapkan-manajemen-usaha-untukbisnis-kecil/

https://qwords.com/blog/menentukan-hargajual-produk/ 